Jurnal Tabarru' : Islamic Banking and Finance

Volume 3 Nomor 2, November 2020

p-ISSN 2621-6833

e-ISSN 2621-7465

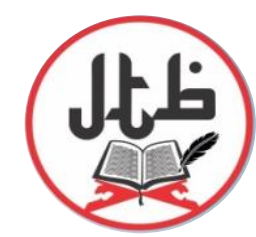

\title{
PEMBIAYAAN MURABAHAH DI BAITUL MAAL WAT TAMWIL (BMT)
}

\author{
Ficha Melina \\ Fakultas Agama Islam (FAI), Universitas Islam Riau (UIR) \\ Email: fichamelina@fis.uir.ac.id
}

\begin{abstract}
ABSTRAK
Industri perbankan mempunyai peranan yang kompleks terhadap perekonomian yang dapat kita rasakan seperti sekarang ini, dimana hampir seluruh aspek kehidupan manusia tidak dapat dipisahkan dengan bank atau lembaga keuangan mikro. Faktor penting yang melatarbelakangi lahirnya bank syariah maupun lembaga keuangan mikro syariah adalah pelarangan riba secara tegas dalam Alquran. Salah satu lembaga keuangan mikro syariah yang berbentuk koperasi adalah Baitul Maal wat Tamwil (BMT). Baitul Maal wat Tamwil (BMT) adalah lembaga keuangan syariah yang beroperasi menggunakan gabungan konsep "Baitul Tamwil dan Baitul Maal" dengan target operasionalnya fokus kepada sektor Usaha Kecil Menengah. Salah satu pembiayaan yang sering dilakukan di BMT adalah akad murabahah, yang mana akad murabahah merupakan kontrak jual-beli dimana bank bertindak sebagai penjual sementara nasabah sebagai pembeli. Penelitian ini akan membahas tentang akad murabahah pada Baitul Maal wat Tamwil (BMT), bagaimana konsep Baitul Maal wat Tamwil (BMT) serta pembiayaan murabahah yang ada di Baitul Maal wat Tamwil (BMT).
\end{abstract}

Kata kunci : Pembiayaan, Murabahah, BMT.

\begin{abstract}
The banking industry has a complex role in the economy that we can feel today, where almost all aspects of human life cannot be separated from banks or microfinance institutions. An important factor behind the koran. One of Islamic banks and Islamic microfinance institutions in the form of a cooperative is the Baitul Maal wat Tamwil (BMT). Baitul Maal wat Tamwil (BMT) is a sharia financial institution that operates focus on the Small And Medium Enterprises sector. One of the financing that is often done in BMT is the murabahah contract, in which the murabahah contract is a sale and purchase contract in murabahah contract at Baitul Maal wat Tamwil (BMT), how the concept of Baitul Maal wat Tamwil (BMT) and murabahah financing in Baitul Maal wat Tamwil $(B M T)$.
\end{abstract}

Keywords : Financing, Murabaha, BMT. 


\section{PENDAHULUAN}

Industri dalam perekonomian Indonesia semakin besar dan penting dari tahun ketahun. Kontribusi sektor industri semakin meningkat. Peranan sektor industri sangat mempengaruhi kesinambungan pertumbuhan ekonomi Indonesia (Mudrahat, 2007). Industri perbankan mempunyai peranan yang kompleks terhadap perekonomian yang dapat kita rasakan seperti sekarang ini, dimana hampir seluruh aspek kehidupan manusia tidak dapat dipisahkan dengan bank atau lembaga keuangan mikro.

Perkembangan perbankan dengan menggunakan prinsip syariah atau lebih dikenal dengan nama bank syariah ataupun lembaga keuangan mikro syariah (LKMS) di Indonesia, bukan merupakan hal yang asing lagi. Namun sejak tahun 1992, telah muncul lembaga keuangan yang berbasis syariah yang melarang praktek konsep bunga ( $r i b a$ ) pada operasional mereka. Faktor penting yang melatarbelakangi lahirnya bank syariah maupun lembaga keuangan mikro syariah adalah pelarangan riba secara tegas dalam Alquran. Riba adalah pengambilan tambahan, baik dalam transaksi jual beli maupun pinjam meminjam secara batil atau bertentangan dengan prinsip muamalah dalam Islam.

Salah satu lembaga keuangan mikro syariah yang berbentuk koperasi adalah Baitul Maal wat Tamwil (BMT). BMT adalah lembaga keuangan syariah yang beroperasi menggunakan gabungan konsep "Baitul tamwil dan Baitul maal" dengan target operasionalnya fokus kepada sektor Usaha Kecil Menengah (UKM). Konsep Baitul tamwil (rumah pengembangan harta), melakukan kegiatan pengembangan usahausaha produktif dan investasi dalam meningkatkan kualitas ekonomi pengusaha mikro dan kecil dengan antara lain mendorong kegiatan menabung dan menunjang pembiayaan kegiatan ekonomi. Sedangkan konsep Baitul maal (rumah harta), menerima titipan dana zakat, infaq dan sedekah serta mengoptimalkan distribusinya sesuai dengan peraturan dan amanahnya (Soemitra, 2009).

Tujuan yang ingin dicapai para penggagasnya tidak lain untuk menampung dana masyarakat dan menyalurkannya kembali kepada masyarakat terutama pengusaha-pengusaha semisal pengusaha muslim yang membutuhkan bantuan modal untuk pengembangan bisnisnya dalam bentuk pemberian fasilitas pembiayaan kepada para nasabah berdasarkan prinsip syariah, seperti murabahah, mudharabah, musyarakah, qardh dan lain-lain (Antonio, 2003).

Salah satu pembiayaan yang sering dilakukan di BMT adalah akad murabahah, yang mana akad murabahah merupakan kontrak jual-beli dimana bank bertindak sebagai penjual sementara nasabah sebagai pembeli. Harga jual adalah harga beli bank ditambah keuntungan. Walaupun akad murabahah ini sering digunakan, namun sebagian masyarakat belum mengerti tentang implementasi akad ini. Sehingga banyak anggapan bahwa praktik pada lembaga keuangan syariah tidak berbeda jauh dengan lembaga keuangan konvensional yang terlebih dahulu dikenal oleh masyarakat luas. Beberapa ketentuan harus dipenuhi dalam melaksanakan akad murabahah agar transaksi akad tersebut terhindar dari riba dan sesuai dengan syariah. Salah satunya adalah syarat barang yang di akadkan dalam hal ini adalah barang yang dijual belikan. Menurut Fatwa Dewan Syariah Nasional MUI No. 04/DSN-MUI/IV/2000 tentang murabahah disebutkan bahwa bank (BMT) harus membeli terlebih dahulu aset yang dipesan oleh nasabah secara sah dan kemudian menawarkan aset tersebut kepada nasabah. Syarat-syarat benda yang menjadi objek akad dalam akad murabahah, barang yang diperjual belikan secara prinsip harus sudah menjadi milik bank (BMT). Tidak sah menjual barang-barang yang baru akan menjadi miliknya. Melalui pendahuluan ini, maka penulis akan mencoba membahas apa itu Baitul Maal wat Tamwil (BMT), pembiayaan murabahah dan margin murabahah. 
Penelitian ini akan membahas tentang akad murabahah pada Baitul Maal wat Tamwil (BMT), bagaimana konsep Baitul Maal wat Tamwil (BMT) serta pembiayaan murabahah yang ada di Baitul Maal wat Tamwil (BMT).

\section{TINJAUAN PUSTAKA}

\section{Konsep Baitul Maal wat Tamwil (BMT)}

Baitul Maal wat Tamwil (BMT) adalah balai usaha mandiri terpadu yang isinya berintikan bayt al-maal wa at-tamwil dengan kegiatan mengembangkan usahausaha produktif dan investasi dalam meningkatkan kualitas kegiatan ekonomi pengusaha kecil bawah dan kecil dengan mendorong kegiatan menabung dan menunjang pembiayaan kegiatan ekonominya. Selain itu, BMT juga dapat menerima titipan zakat, infaq dan sedekah, serta menyalurkannya sesuai dengan peraturan dan amanatnya (Ridwan, 2013).

Baitul Maal wat Tamwil merupakan lembaga keuangan mikro (LKM) yang beroperasi berdasarkan prinsip-prinsip syariah, yang merupakan lembaga keuangan syariah non bank yang bersifat informal karena lembaga ini didirikan oleh Kelompok Swadaya Masyarakat (KSM).

Dengan demikian, keberadaan BMT dapat dipandang memiliki dua fungsi utama, yaitu sebagai media penyalur pendayagunaan harta ibadah seperti zakat, infaq, sedekah dan wakaf, serta dapat pula berfungsi sebagai institusi yang bergerak dibidang investasi yang bersifat produktif sebagaimana layaknya bank. Pada fungsi kedua dapat dipahami bahwa selain berfungsi sebagai lembaga keuangan, BMT juga berfungsi sebagai lembaga ekonomi.

Bait Maal wa al-Tamwil disingkat dengan BMT terdiri dari dua istilah, yaitu Bait al-Maal dan Baitul tamwil. Bait al-maal lebih mengarah pada usaha-usaha pengumpulan dan penyaluran dana yang non profit. Seperti zakat, sedekah, infaq. Sedangkan Baitul tamwil merupakan suatu wadah yang lebih mengarah pada usahausaha pengumpulan dana dan penyaluran dana yang bersifat profit dengan memakai sistem profit and loos sharing, seperti pemberian pembiayaaan murabahah, mudharabah dan lain-lain seabagainya. Bila digabungkan kedua istilah tersebut, maka dapat dijelaskan bahwa BMT adalah balai usaha mandiri terpadu yang isinya berintikan bayt al-maal wa al-tamwil dengan kegiatan menegembangkan usaha-usaha produktif dan investasi dalam meningkatkan kualitas kegiatan ekonomi pengusaha kecil untuk mendorong kegiatan menabung dan menunjang pembiayaan kegiatan ekonominya. Selain itu BMT juga bisa menerima titipan zakat, sedekah dan infaq serta menyalurkannya sesuai dengan yang telah ditentukan dalam syariat Islam (A.Djazuli, 2002).

Menurut Azis menjelaskan bahwa BMT adalah lembaga usaha kecil ke bawah berdasarkan sistem bagi hasil dan jual beli dengan memfaatkan potensi jaminan dalam lingkunganya sendiri. (Aziz, 2000)

Dari pengertian diatas, dapat dipahami bahwa pola pengembangan institusi keuangan ini diadopsi dari bait almaal yang ada pada masa Rasulullah SAW dan Khlifah al-Rasyidin. Oleh karena itu, keberadaan BMT selain bisa dianggap sebagai media penyalur, pendayagunaan harta zakat, sedekah, infaq juga bisa dianggap sebagai institusi yang bergerak dibidang investasi yang bersifat produktif seperti layaknya bank.

BMT selain berfungsi sebagai lembaga keuangan juga dapat berfungsi. Sebagai lembaga ekonomi, sebagai lembaga keuangan, ia bertugas menghimpun dana dari masyarakat dan menyalurkan pada masyarakat. Sebagai lembaga ekonomi, ia berhak melakukan kegiatan ekonomi, seperti perdagangan industri dan pertanian. Beranjak dari pengertian diatas, maka BMT dapat lebih dipahami dari segi ciri-ciri yang dimilikinya. Ciri-ciri BMT ini diungkapkan dalam redaksi yang berbeda-beda oleh para ilmuan. Muhammad menjelaskan bahwa BMT memiliki ciri-ciri sebagai berikut (Muhammad, 2000): 
1) Lembaga ini haruslah mudah untuk didirikan, artinya lembaga ini harus sederhana untuk dapat ditangani dan dimengerti oleh pengusaha yang sebagian besar berpendidikan S1 atau setingkat.

2) Semua yang terlibat memiliki motivasi kuat untuk bukan saja mendirikan, tetapi juga membina dan mengembangkan lebih lanjut, oleh karena itu lembaga tersebut harus berkait dengan kepentingan yang mendasar dari pemiliknya.

3) Lembaga ini tidak saja memiliki aturan-aturan kerja yang lentur, efisien dan efektif, tetapi juga mandiri.

4) Transaksi-transaksi bisnis semuanya dilakukan atas dasar bagi hasil (mudharabah).

5) BMT tempat mencerdaskan kehidupan pengusaha kecil melalui kegiatan ikraqdan penggalangan kedalam yang dilakukan secara kontinyu.

6) Memiliki sifat amanah dan saling percaya mempercayai dan diikuti dengan kegiatan-kegiatan keagamaan yang mengingatkan dan menanamkan prinsip-prinsip moral intelektual keagamaan kepada anggota.

Abd. Majid (2000), menjelaskan bahwa ciri-ciri BMT adalah sebagai berikut:

1) Usahanya dimaskud untuk mendorong sikap dan perilaku menabung dari masyarakat banyak dengan menerima simpanan atas dasar balas jasa berdasarkan bagihasil (mudharabah).

2) Pengelolaanya secara profesional persis mengikuti administrasi pembukuan dan prosedur perbankan dengan pengecualian tidak mengharuskan pakai jaminan uang atau harta benda untuk pinjaman yang kecil dibawah $\mathrm{Rp}$. 500.000,-

3) Modal awal untuk mendirikan BMT lebih kurang Rp. 3.000.000,- sampai dengan Rp. 10.000.000,- ditambah fasilitas sarana sekitar Rp. 1.000.0000,sampai Rp. 1.500.000,-

4) Pendiri sebagai anggota inti yang mau menyimpan modal awal.

5) Biaya operasional sangat rendah, antara lain karena kecilnya jumlah staf dan dapat beroperasi pada kondisi yang sederhana.

6) Jaminannya adalah mengutamakan kepercayaan, karena daerah operasinya tidak luas.

7) Mitra operasi terintegrasi dengan lembaga lokal, misalnya pengajian, lingkungan mesjid dan pesantren.

Ciri-ciri utama BMT menurut A. Djazuli (2002) adalah:

1) Berorientasi bisnis, mencari laba bersama, meningkatkan pemanfaatan ekonomi paling banyak untuk anggota dan lingkungan.

2) Bukan lembaga sosial, tetapi tidak dapat dimanfaatkan mengefektifkan penggunaan zakat, infaq dan sedekah bagi kesejahteraan orang banyak.

3) Ditumbuhkan dari bawah berdasarkan peran serta masyarakat disekitarnya.

4) Milik bersama masyarakat kecil bukan milik orang dari luar.

Selain ciri utama di atas, BMT menurut A. Djazuli (2020) juga memiliki ciri khas sebagai berikut:

1. Staf dan karyawan BMT bertindak aktif, dinamis, berpandangan produktif, tidak menunggu tetapi menjeput nasabah, baik sebagai penyetor dana maupun penerima pembiayaan usaha.

2. Kantor dibuka dalam waktu tertentu dan ditunggui oleh sejumlah staf yang terbatas, karena sebagian staf harus bergerak di lapangan untuk mendapatkan nasabah penyetor dana, memonitor dan mensurvei usaha nasabah.

3. BMT mengadakan perjanjian rutin secara berkala yang waktu dan 
tempatnya di madrasah, mesjid, setelah pengajian bisa dilanjutkan dengan membicarakan bisnis dari para nasabah BMT.

4. Manajemen BMT diselenggarakan secara profesional dan Islami.

Adapun profil BMT secara umum menurut Soemitra (2017) sebagai berikut:

a. Tujuan dari BMT yaitu meningkatkan kualitas usaha ekonomi untuk kesejahteraan anggota pada khususnya dan masyarakat pada umumnya.

b. Sifat BMT, yaitu memiliki usaha bisnis yang bersifat mandiri, ditumbuhkembangkan dengan swadaya dan dikelola secara profesional serta berorientasi untuk kesejahteraan anggota dan masyarakat lingkungannya.

c. Visi BMT, yaitu menjadi lembaga keuangan yang mandiri, sehat dan kuat, yang kualitas ibadah anggotanya meningkat sedemikian rupa sehingga mampu berperan menjadi wakil pengabdi Allah SWT memakmurkan kehidupan anggota pada khususnya dan umat manusia pada umumnya.

d. Misi BMT, yaitu mewujudkan gerakan pembebasan anggota dan masyarakat dari belenggu rentenir, jerat kemiskinan dan ekonomi ribawi, gerakan pemberdayaan meningkatkan kapasitas dalam kegiatan ekonomi rill dan kelembagaannya menuju tatanan perekonomian yang makmur dan maju dan gerakan keadilan membangun struktur masyarakat madani yang adil dan berkemakmuran berkemajuan, serta makmur maju berkeadilan berdasarkan syariah dan ridho Allah SWT.

e. Fungsi BMT yaitu (1) mengidentifikasi, memobilisasi, mengorganisir, dan mengembangkan potensi serta kemampuan ekonomi anggota, kelompok usaha anggota muamalat (Pokusma) dan kerjanya, (2) mempertinggi kualitas SDM anggota dan Pokusma menjadi lebih profesional dan Islami sehingga semakin utuh dan tangguh menghadapi tantangan global, (3) menggalang dan mengorganisir potensi masyarakat dalam rangka meningkatkan kesejahteraan anggota.

\section{Prinsip Operasional BMT}

BMT merupakan lembaga keuangan syariah dengan sistem bagi hasil, dalam mengelola dana yang ada BMT menggunakan beberapa prinsip operasionalnya, sebagaimana dijelaskan oleh Sudarsono (2003) sebagai berikut:

1) Prinsip bagi hasil setiap jenis usaha yang di dalamnya ada prinsip bagi hasil, maka akan ada pembagian hasil antara BMT dengan nasabahnya.

2) Prinsip jual beli prinsip ini merupakan suatu tata cara jual beli yang dalam pelaksanaannya BMT mengangkat nasabah sebagai agen yag diberi kuasa melakukan pembelian barang atas nama BMT, dan kemudian bertindak sebagai penjual dengan menjual barang yang telah dibelinya tersebut ditambah markup. Keuntungan yang didapat BMT akan dibagi bersama dengan penyedian dana berdasarkan kesepakatan.

3) Prinsip non profit Ini merupakan suatu prinsip yang sering disebut sebagai pembiayaan kebajikan atau pembiayaan yang bersifat sosial dan non komersial. Dalam pembiayaan ini nasabah cukup mengembalikan pokok pinjamanya saja.

4) Prinsip akad bersyarikat akad bersyarikat adalah kerjasama antara dua pihak atau lebih yang masing-masing pihak mengikutsertakan modal dalam berbagai bentuk dengan perjanjian pembagian keuntungan atau kerugian yang disepakati.

5) Prinsip pembiayaan penyediaan uang dan tagihan berdasarkan persetujuan atau kesepakatan pinjam meminjam diantara BMT dengan pihak lain, yang mewajibkan pihak pinjaman untuk melunasi hutangnya beserta bagi hasil setelah jangka waktu tertentu. 
Disamping prinsip di atas, pada BMT juga terdapat prinsip-prinsip non bisnis lainya dalam operasionalnya, seperti dalam produk input dana ibadah, seperti zakat, infaq, sedekah yang diserahkan langsung pada yang berhak menerimanya.

\section{Konsep Pembiayaan}

Berdasarkan Undang-Undang Nomor 10 tahun 1998 tentang Perbankan Bab I Pasal 1 Nomor 12, yang dimaksud pembiayaan berdasarkan prinsip syariah adalah penyediaan uang atau tagihan yang dapat dipersamakan dengan itu berdasarkan persetujuan atau kesepakatan antara bank dengan pihak lain yang mewajibkan pihak yang dibiayai untuk mengembalikan uang atau tagihan tersebut setelah jangka waktu tertentu dengan imbalan atau bagi hasil (Kasmir, 2012).

Pembiayaan merupakan kegiatan bank syariah dan lembaga keuangan lainnya dalam menyalurkan dananya kepada pihak anggota yang membutuhkan dana. Pembiayaan sangat bermanfaat bagi bank syariah maupun BMT, nasabah dan pemerintah. Pembiayaan memberikan hasil yang besar diantara penyaluran dana lainnya yang dilakukan oleh bank syariah. Sebelum menyalurkan dana melalui pembiayaan, bank syariah perlu melakukan analisis pembiayaan yang mendalam, Sehingga kerugian dapat dihindari (Ismail, 2011).

Dalam buku yang ditulis oleh Muhammad (2005) pembiayaan atau financing adalah pendanaan yang diberikan oleh suatu pihak kepada pihak lain untuk mendukung investasi yang telah direncanakan, baik dilakukan sendiri maupun lembaga. Dengan kata lain, pembiayaan adalah pendanaan yang dikeluarkan untuk mendukung investasi yang telah direncanakan.

Pembiayaan yaitu pendanaan yang dikeluarkan untuk mendukung investasi yang telah direncanakan, baik dilakukan sendiri maupun dikerjakan oleh orang lain. Tujuan pembiayaan berdasarkan prinsip syariah adalah untuk meningkatkan kesempatan kerja dan kesejahteraan ekonomi sesuai dengan nilai-nilai Islam. Pembiayaan tersebut harus dapat dinikmati oleh sebanyak-banyaknya pengusaha yang bergerak dibidang industri, pertanian, dan perdagangan untuk menunjang kesempatan kerja dan menunjang produksi dan distribusi barang-barang dan jasa-jasa dalam rangka memenuhi kebutuhan dalam negeri maupun ekspor. Memberikan pembiayaan dengan prinsip syariah yang menerapkan sistem bagi hasil yang tidak memberatkan debitur. (Melina, 2018).

Tujuan pembiayaan secara makro untuk meningkatkan ekonomi umat, tersedianya dana bagi peningkatan usaha, meningkatkan produktifitas, membuka lapangan kerja baru, dan terjadi distribusi pendapatan. Sedangkan secara mikro pembiayaan diberikan dengan tujuan memaksimalkan laba, meminimalkan resiko, penyalahgunaan sumber ekonomi, dan penyaluran kelebihan dana (Muhammad, 2005).

Sesuai dengan tujuan pembiayaan tersebut, maka pembiayaan memiliki fungsi sebagai berikut: meningkatkan daya guna uang, meningkatkan daya guna barang, meningkatkan kegairahan usaha, stabilitas ekonomi, dan sebagai jembatan untuk meningkatkan pendapatan nasional (Muhammad, 2005).

\section{Konsep Murabahah}

Menurut M. Syafi'i Antonio dalam bukunya mengartikan bahwa Murabahah adalah jual beli barang pada harga asal dengan tambahan keuntungan yang disepakati. Dalam hal ini, penjual harus memberikan pokok produk yang ia beli dan menentukan suatu tingkat keuntungan sebagai tambahan, menentukan lama pembiayaan dan besar angsuran yang akan diangsur (Antonio, 2003).

Murabahah didefinisikan oleh para Fuqaha sebagai penjualan barang seharga biaya/harga pokok (cost) barang tersebut ditambah mark-up atau margin keuntungan yang disepakati. Murabahah adalah jual beli barang pada harga asal dengan tambahan keuntungan yang disepakati. Karakteristik 
murabahah adalah penjual harus memberi tahu harga yang ia beli dan menentukan suatu tingkat keuntungan sebagai tambahannya.

Murabahah merupakan salah satu produk penyaluran dana yang cukup di gemari BMT karena karakternya yang profitable, mudah dalam penerapan, BMT bertindak sebagai pembeli sekaligus penjual barang halal tertentu yang dibutuhkan nasabah. Mula-mula BMT membeli barang sebagaimana dimaksud kepada pihak ketiga dengan harga tertentu, secara langsung atau melalui wakil yang ditunjuk, untuk selanjutnya barang tersebut dijual kepada nasabah dengan harga tertentu setelah ditambah keuntungan (mark-up) yang disepakati bersama (Wiroso, 2005).

Murabahah merupakan kontrak jualbeli dimana bank bertindak sebagai penjual sementara nasabah sebagai pembeli. Harga jual adalah harga beli bank ditambah keuntungan. Walaupun akad murabahah ini sering digunakan, namun sebagian masyarakat belum mengerti tentang implementasi akad ini. Sehingga banyak anggapan bahwa praktik pada lembaga keuangan syariah tidak berbeda jauh dengan lembaga keuangan konvensional yang terlebih dahulu dikenal oleh masyarakat luas (Melina dan Zulfa, 2020).

Sedangkan menurut Haitam dalam jurnal Haryoso (2017) murabahah adalah sebuah pergeseran kepemilikan sesuatu yang dimiliki yang kemudian dijual dengan harga pertama lalu diberikan sedikit tambahan keuntungan. Dari beberapa definisi di atas pada dasarnya sama, yakni murabahah merupakan kegiatan jual beli dimana penjual memberi tahukan atau menceritakan biaya perolehan barang yang sesungguhnya kepada konsumen lalu ditambahkan keuntungan atas penjualan barang tersebut berdasarkan biaya yang dikeluarkan dan kesepakatan antara penjual dan pembeli.

\section{Landasan Hukum Pembiayaan Murabahah}

Murabahah merupakan bagian terpenting dari jual beli dan prinsip ini mendominasi pendapatan bank dari produkproduk yang ada di semua bank Islam serta lembaga keuangan syariah lainnya. Dalam Islam, jual beli sebagai sarana tolong menolong antara sesama umat manusia yang diridhai oleh Allah SWT.

Firman Allah SWT dalam QS. AlBaqarah ayat 275:

Artinya: "Dan Allah SWT telah menghalalkan jualbeli dan mengharamkan riba."

Firman Allah SWT dalam QS. AlMaidah ayat 1:

Artinya: "Hai orang-orang yang beriman, penuhilah akad-akad itu."

Firman Allah SWT dalam QS. AnNisa ayat 29

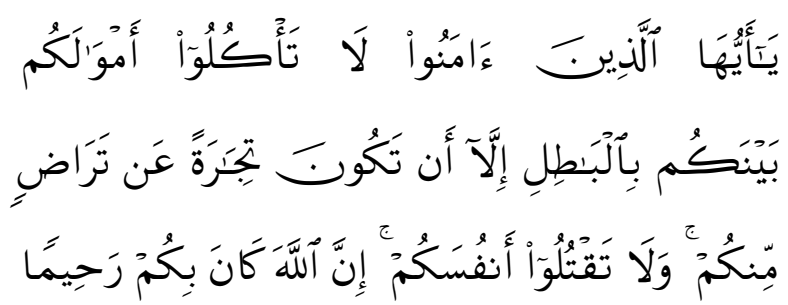

Artinya :"Hai orang-orang yang beriman, janganlah kamu saling memakan harta sesamamu dengan jalan yang batil, kecuali dengan jalan perniagaan yang berlaku dengan suka sama-suka di antara kamu. Dan janganlah kamu membunuh dirimu; sesungguhnya Allah SWT adalah Maha Penyayang kepadamu."

Dalam surat An-Nisa ayat 29 merupakan larangan tegas mengenai memakan harta orang lain dengan jalan bathil, kecuali dengan jalan perniagaan yang berlaku atas suka sama suka. Memakan dengan cara yang bathil maksudnya adalah memakannya dengan jalan riba, judi, menipu, menganiaya dan hal-hal yang dilarang Allah SWT. Akan tetapi 
diperbolehkan bagi kalian untuk mengambil harta milik selainmu dengan cara dagang yang lahir dari keridhaan dan keikhlasan hati antara dua pihak (atas suka sama suka), dalam jual beli diperbolehkan kita untuk mengambil keuntungan dari barang yang diperjualbelikan sesuai dengan akad diawal.

Hadis Nabi riwayat Tirmidzi:

Artinya : "Perdamaian dapat dilakukan di antara kaum Muslimin kecuali perdamaian yang mengharamkan yang halal atau menghalalkan yang haram; dan kaum Muslimin terikat dengan syarat-syarat mereka kecuali syarat yang mengharamkan yang halal atau menghalalkan yang haram." (HR. Tirmizi dari Amr bin Auf).

\section{Ketentuan Murabahah}

Ketentuan murabahah diatur pula dalam Fatwa DSN No. 04/SDSNMUI/IV/2000 yaitu:

a. Bank dan nasabah harus melakukan akad murabahah yang bebas riba.

b. Barang yang dijual belikan tidak diharamkan oleh syariat Islam.

c. Bank membiayai sebagian atau keseluruhan harga pembelian barang yang telah disepakati kualifikasinya.

d. Bank membeli barang yang diperlukan nasabah atas nama bank sendiri, dan pembeli ini harus sah dan bebas riba.

e. Bank harus menyampaikan semua hal yang berkaitan dengan pembelian, misalnya jika pembelian barang dilakukan secara utang. Bank kemudian menjual barang tersebut kepada nasabah dengan harga senilai harga plus keuntungannya. Dalam kaitan ini bank harus memberitahu secara jujur harga pokok barang kepada nasabah berikut biaya yang diperlukan.

f. Nasabah membayar harga barang pada jangka waktu tertentu yang telah disepakati. g. Untuk mencegah terjadinya penyalahgunaan atau kerusakan akad pihak bank dapat mengadakan perjanjian khusus dengan nasabah.

h. Jika bank hendak mewakilkan kepada nasabah untuk membeli barang dari pihak ketiga, akad jual beli murabahah harus dilakukan setelah barang secara prinsip menjadi milik bank (Wiroso, 2005).

\section{METODE PENELITIAN}

Penelitian ini merupakan jenis penelitian kepustakaan (library research), dimana data-data yang dipakai adalah data kepustakaan. Di dalam penelitian ini, analisis data didasarkan pada teori mengenai pembiayaan murabahah serta aplikasi pembiayaan murabahah pada BMT.

\section{HASIL DAN PEMBAHASAN}

\section{Aplikasi Pembiayaan Murabahah pada BMT}

Pembiayaan berdasarkan prinsip jual beli merupakan penyediaan barang modal kerja maupun investasi. Atas transaksi ini, BMT akan memperoleh sejumlah keuntungan. Karena sifatnya jual beli, maka transaksi ini harus memenuhi syarat dan rukun jual beli.

Bagi BMT yang memiliki sektor riil, penyediaan barang modal dapat dipenuhi secara langsung, namun bagi yang tidak memiliki sektor riil atau karena sektor riil yang ada tidak mampu memenuhi kebutuhan, maka BMT dapat bekerja sama dengan suplier atau agent penyedia. Mekanisme jual beli ini meliputi:

a. Anggota atau nasabah mengajukan secara rinci kebutuhan barang yang akan dibeli. Rincian barang-barang tersebut dapat berupa jenis, merek, tahun pembuatan, warna, ukuran bentuk sampai pada tempat pembelian. Semakin terinci akan semakin baik.

b. BMT bersama-sama anggota atau nasabah yang membutuhkan akan 
melihat dengan pasti tentang barang yang dimaksud.

c. BMT akan membeli barang tersebut kepada suplier, dengan harga pokok yang diketahui kedua belah pihak.

d. BMT kemudian akan menjual kembali barang tersebut kepada anggota atau nasabah yang membutuhkan seharga pembelian pokok ditambah keuntungan (margin) yang disepakati. e. Jika kondisi tidak memungkinkan bagi BMT untuk membeli terlebih dahulu barang tersebut, maka BMT akan memberikan kuasa kepada anggota untuk membeli sendiri kemudian nota pembeliannya diberitahukan kepada BMT (Ridwan, 2014).

Adapun skema pembiayaan murabahah dijelaskan melalui gambar berikut:

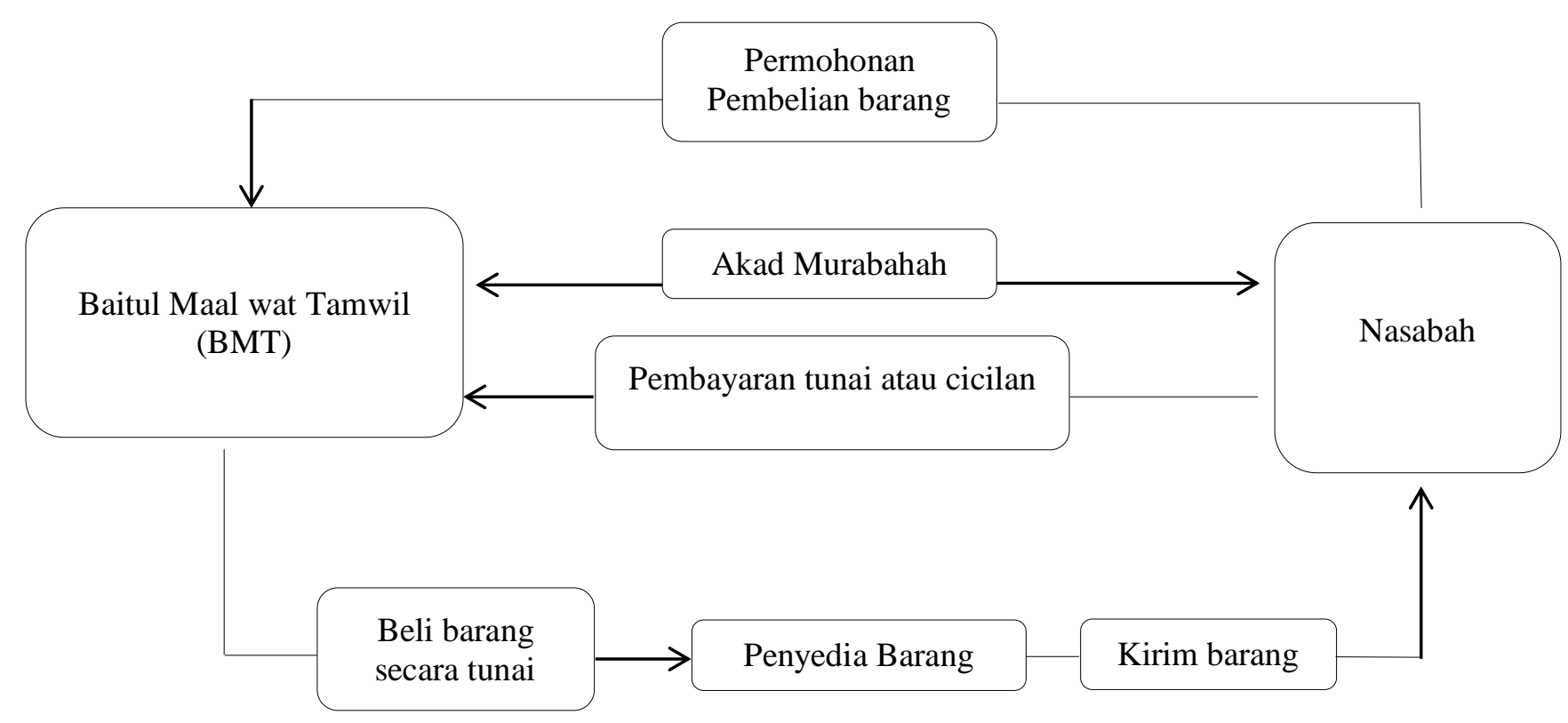

Sumber: Ilustrasi Penulis (2020)

Dari skema murabahah di atas dapat penulis jelaskan sebagai berikut:

1) Nasabah mengajukan permohonan dan janji pembelian barang kepada BMT sesuai dengan kriteria yang dibutuhkan. Namun sebelumnya, pastikan nasabah telah terdaftar sebagai anggota dari BMT tersebut sehingga BMT telah memiliki identitas nasabah tersebut.

2) BMT membeli barang yang diminta oleh nasabah kepada penyedia barang (pihak ketiga) sesuai dengan kriteria yang ditentukan oleh nasabah. Pembelian barang kepada penyedia barang dilakukan secara tunai.
Sehingga, hak kepemilikan barang tersebut sudah berada ditangan BMT.

3) Setelah melakukan pembelian barang kepada penyedia barang (supplier) dan sebelum barang tersebut diserahkan kepada nasabah. Pihak BMT dan nasabah mengikatkan diri ke dalam suatu perjanjian akad murabahah. Didalam perjanjian inilah BMT menyebutkan harga pokok pembelian tersebut kepada nasabah, serta BMT menyebutkan keuntungan yang akan diambil kepada nasabah. Dua hal tersebut harus disepakati diawal perjanjian. BMT diperbolehkan meminta uang muka kepada nasabah saat menandatangani perjanjian jual beli. Apabila nasabah menolak 
membeli barang tersebut, biaya perolehan barang yang telah dikeluarkan BMT harus diganti oleh nasabah denga membayar uang muka. Namun, apabila uang muka dari nasabah masih kurang dalam menutupi kerugian BMT, BMT berhak meminta kembali sisa kerugian yang masih belum dibayar oleh BMT.

4) Setelah BMT dan nasabah menyepakati perjanjian jual beli tersebut, BMT akan mengirimkan barang kepada nasabah.

5) Nasabah membayar barang tersebut sesuai dengan harga jual yang telah disepakati diawal. Pembayaran secara tunai maupun cicilan.

\section{Rukun dan Syarat Murabahah}

Rukun dari akad murabahah yang harus dipenuhi dalam transaksi ada beberapa yaitu:

a. Pelaku akad yaitu $b a^{\prime} i$ (penjual) adalah pihak yang memiliki barang untuk dijual dan musytari (pembeli) adalah pihak yang memerlukan dan akan membeli barang.

b. Objek akad, yaitu mabi' (barang dagangan) dan tsaman (harga).

c. Shighah, yaitu ijab dan qabul.

Sedangkan syarat akad murabahah, antara lain :

a. Mengetahui harga pertama (harga pembelian) baik kedua belah pihak.

b. Mengetahui besarnya keuntungan, mengetahui jumlah keuntungan adalah keharusan, karena ia merupakan bagian dari harga (tsaman), sedangkan mengetahui harga adalah syarat sahnya jual beli.

c. Modal hendaknya berupa komoditas yang memiliki kesamaan dan sejenis, seperti benda-benda yang ditakar, ditimbang dan dihitung. Jika modal dan benda-benda yang tidak memiliki kesamaan, seperti barang dagangan, selain dirham dan dinar, tidak boleh diperjual belikan dengan cara murabahah oleh pihak yang tidak memiliki barang dagangan. Hal ini karena murabahah adalah jual beli dengan harga yang sama dengan harga pertama, dengan adanya tambahan keuntungan dalam sistem murabahah.

d. Sistem murabahah dalam harta riba hendaknya tidak menisbatkan riba tersebut terhadap harga pertama. Seperti membeli barang yang ditakar atau ditimbang dengan barang sejenis dengan takaran yang sama, maka tidak boleh menjualnya dengan sistem murabahah. Hal semacam ini tidak diperbolehkan karena murabahah adalah jual beli dengan harga pertama dengan adanya tambahan, sedangkan tambahan terhadap harta riba hukumnya adalah riba dan bukan keuntungan.

e. Transaksi pertama haruslah sah secara syara (Wiroso, 2005).

Dalam Murabahah ada beberapa syarat dalam akad jual beli, antara lain:

1) Syarat mengadakan akad

a) Syarat orang yang berakad: Orang berakad harus berakal, bisa membedakan mana yang benar dan mana yang salah, serta orang yang berakad harus banyak berperan (tempat akad dilaksanakan dalam satu majelis).

b) Barang yang berakad harus memenuhi syarat, antara lain:

c) Barangnya harus ada

d) Barangnya berupa harta yang jelas harganya

e) Barangnya dimiliki sendiri, artinya terjaga 
f) Barang itu dapat diserahkan sewaktu akad.

2) Syarat-syarat pelaksanaan akad :

a) Pemilikan atau penguasaan, pemilikan adalah penguasaan barang ketika orang yang melakukannya mampu bertasharruf sendiri pada barang itu tanpa ada penghalang syariah.

b) Dalam barang yang akan diperjualbelikan hanya terdapat hak penjual, artinya barang yang di jual tidak ada hak orang lain selain penjual itu sendiri (Wiroso, 2005).

\section{Margin Dalam Murabahah}

Pendapat ahli hukum Islam menjelaskan mengenai biaya yang dapat ditambahkan ke harga dan merupakan dasar untuk perhitungan laba. Menurut Hanafi semua biaya yang diterima dari praktek komersial atau jual beli dapat ditambahkan ke harga biaya mengenai biaya perolehan dari komoditas tersebut. Menurut Hanbali dan Imam Shafi'i semua biaya aktual yang terjadi sehubungan pembelian komoditas dapat ditambahkan asalkan ada kesepakatan dengan nasabah. Menurut Maliki biaya yang dapat ditambahkan kedalam harga adalah biaya yang dikeluarkan seperti penyimpanan barang atau biaya pengangkutan, namun biaya tersebut tidak termasuk dalam keuntungan dan untuk keuntungan dapat ditambahkan lagi (Mansuri, 2006).

Selain itu penetapan margin pada murabahah menurut otoritas jasa keuangan ada beberapa poin, sebagai berikut:

a. Margin jual Murabahah merupakan tingkat keuntungan yang diharapkan (expected yield) oleh lembaga keuangan syariah.

b. Margin (mark up price) ditentukan berdasarkan kesepakatan antara lembaga keuangan syariah dan Nasabah.

c. Margin dinyatakan dalam bentuk nominal atau persentase tertentu dari harga pokok lembaga keuangan syariah.

d. Perhitungan margin dapat mengacu pada tingkat imbalan yang berlaku umum pada pasar keuangan dengan mempertimbangkan ekspektasi biaya dana, risk premium dan tingkat keuntungan.

e. Margin tidak boleh bertambah sepanjang masa pembiayaan setelah kontrak disepakati dan ditandatangani kedua belah pihak.

f. Lembaga keuangan syariah dapat memberikan potongan margin Murabahah sepanjang tidak menjadi kewajiban Bank yang tertuang dalam perjanjian.

\section{KESIMPULAN}

Dalam perkembangan dewasa ini lembaga keuangan non bank berkembang dan diwujudkan dalam berbagai bentuk. Salah satu lembaga keuangan nonbank yang berkembang saat ini adalah Baitul maal wa tamwil (BMT). Dalam tulisan ini dibahas mengenai konsep Baitul maal wa tamwil (BMT), landasan hukum Baitul maal wa tamwil (BMT), konsep pembiayaan dan konsep murabahah, aplikasi modern murabahah dan skema pembiayaan murabahah, margin dalam murabahah serta ketentuan akad murabahah.

\section{DAFTAR RUJUKAN}
A.Djazuli. 2002. lembaga-lembaga Perekonomian Umat (sebuah pengenalan). Raja Grafindo Persada. Jakarta.

Abd. Majid, Baihaqi. 2000. Paradigma Ekonomi Kerakyatan Sistem Syariah Pinbuk. Jakarta. 
Antonio, Syafi`i. Muhammad. 2003. Bank Syariah dari Teori Ke Praktek. PT Era Adi Citra. Solo.

Aziz, Amin. Muhammad. 2000. Paradigma Baru Ekonomi Kerakyatan Sistem Syariah: Perjalanan, Gagasan dan Gerakan BMT di Indonesia. Gema Insani. Jakarta.

Haryoso, Lukman. 2017. Penerapan Prinsip Pembiayaan Syariah (Murabahah) Pada BMT Bina Usaha Di Kabupaten Semarang. Jurnal Law and Justice, 2 (1), 79-89.

Ismail. 2011. Perbankan Syariah. Kencana. Jakarta.

Kasmir. 2012. Manajemen Perbankan. Rajawali Pers. Jakarta.

Mansuri, M. Tahir. 2006. Islamic Law Of Contracts And Business Transactions. Adam Publisher And Distribution. New Delhi.

Melina, Ficha. \& Zulfa. Marina. 2020. Implementasi Pembiayaan Murabahah pada Baitul Maal wat Tamwil (BMT) Kota Pekanbaru. COSTING: Journal of Economic, Business and Accounting, 3(2), 356-364.

Melina, Ficha. 2018. Pembiayaan Pinjaman Lunak Usaha Kecil Ikan Patin dengan PT. Telkom Pekanbaru Melalui Mitra Binaan Menurut Ekonomi Islam. Syarikat: Jurnal Rumpun Ekonomi Syariah, 1(1), 5362.

Mudrahat, Kuncoro. 2007. Ekonomika Industri Indonesia, Andi. Yogyakarta.

Muhammad. 2000. Lembaga Keuangan Umat Kontemporer. UII Press. Yogyakarta.
Muhammad. 2005. Manajemen Pembiayaan Bank Syariah. UPP AMP YKPN. Yogyakarta.

Ridwan, Hasan Ahmad. 2013. Manajemen Baitul Maal wat Tamwil. CV Pustaka Setia. Bandung.

Ridwan. Muhammad, 2014. Manajemen Baitul Maal wat Tamwil (BMT). UII Press. Yogyakarta

Soemitra, Andri. 2017. Bank dan Lembaga Keuangan Syariah. Prenada Media. Jakarta.

Sudarsono, Heri. 2003. Bank Lembaga Keuangan Syariah (Deskripsi dan Ilustrasi). Ekonisia. Yogyakarta.

Wiroso. 2005. Jual Beli Murabahah. UII Press. Yogyakarta. 